TP Periodica Polytechnica Civil Engineering

62(4), pp. 1060-1066, 2018 https://doi.org/10.3311/PPci.12173

Creative Commons Attribution (i)

RESEARCH ARTICLE

\section{Influence of Water Content on the Mechanical Parameters of the Intact Rock and Rock Mass}

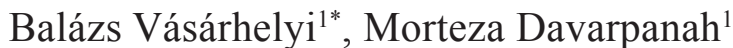

Received 02 March 2018; Revised 27 March 2018; Accepted 17 September 2018

\begin{abstract}
The goal of this paper is to present the influence of the water saturation of the intact rock on different mechanical parameters, such as internal friction angle, cohesion, Hoek-Brown constant $\left(m_{i}\right)$. Analyzing the previously published results, it was found that due to water saturation both the uniaxial compressive strength and tensile strength decrease similarly, i.e. the ratio of these two values is constant, thus the internal friction angle does not change but only the cohesion. Likewise, Hoek-Brown constant $\left(m_{i}\right)$ remains constant; it is independent on the moisture content.

The ratio of the elastic modulus and the uniaxial compressive strength of the intact rock is also calculated. According to the laboratory results, this ratio (namely modulus ratio) is also independent on the water content.

It is shown that the mechanical parameters of the rock mass (such as compressive strength, tensile strength, deformation modulus) similarly depend on the water content than the intact rock.
\end{abstract}

\section{Keywords}

rock mechanics, water saturation, mechanical parameters, internal friction angle, cohesion, rock mass

\section{Introduction}

Recently, several researches have carried out various studies focusing on the influence of the water content on the mechanical parameters (e.g. uniaxial compressive strength, tensile strength, modulus of elasticity) of the intact rock. Wong et al. [1] collected the most important results in their review article.

According to the laboratory tests results, different mechanical parameters decrease due to increasing moisture content of the rock. Hawkins \& McConnell [2] investigated the influence of the moisture content on the strength of the rock and they suggested the following form:

$$
\sigma_{c}(w)=a e^{-b w}+c,
$$

where $\sigma_{c}(w)$ is the uniaxial compressive strength (MPa), $w$ is the water content (\%) and $a, b$ and $c$ are material constants. It is obvious that the strength at zero water content $\sigma_{c}(0)=a+c$, and the strength at full saturation $\sigma_{c}(s a t)=c$. The schematic curve is plotted in Figure 1.

The parameter $b$ is a dimensionless constant defining the rate of strength loss with increasing water content. According to the large number tests (investigated different British sandstones by [2]) these material constants are between 4.16-84.01; $0.0752-6.147 ; 2.97-231$ for $a, b$ and $c$, respectively.

Hawkins \& McConnell [2] did not investigate the relationships between these material constants. However, it was not goal to analyse the published data, but it should be noted: parameter $b$ can linearly depend on parameter $a$ (see Fig. 2).

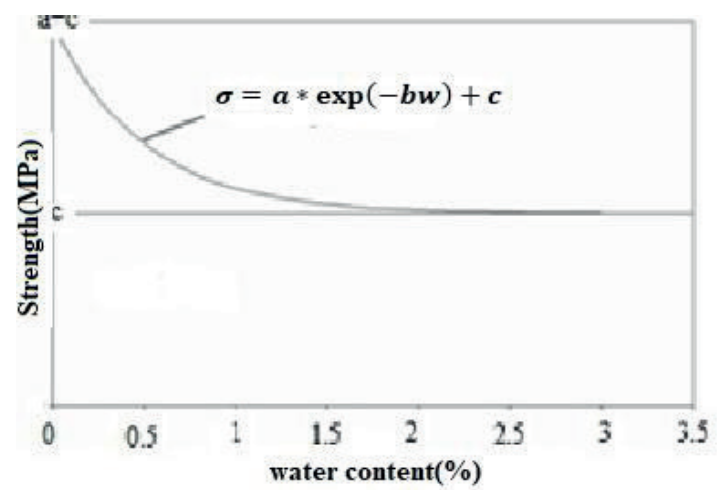

Fig. 1 Influence of the water content on the strength of the rock - schematic curve according to Eq. (1) [2] 


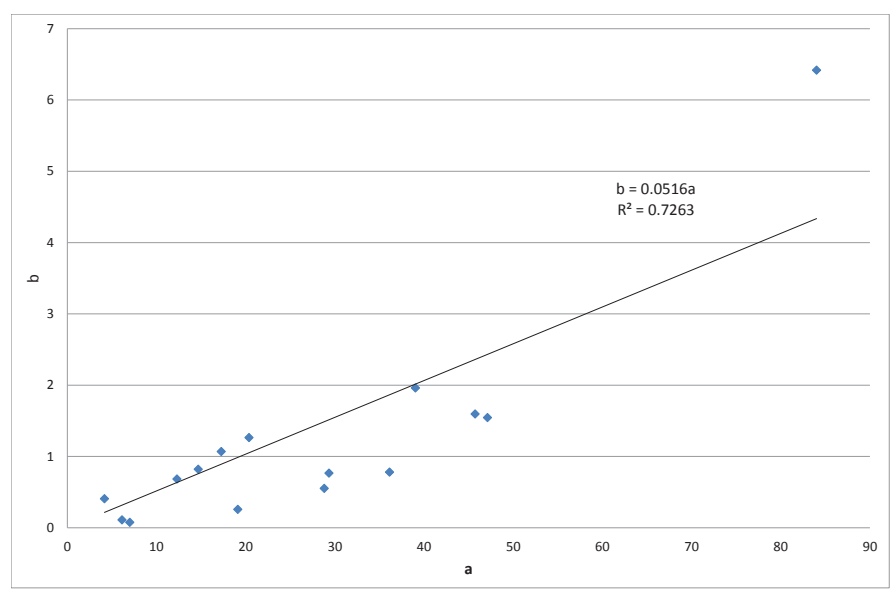

Fig. 2 Connection between parameters $a$ and $b$ (Eq. (2), data from Hawkins $\&$ McConnell [2]).

The disadvantage of the analysis method of Hawkins \& McConnell [2] is that the saturated condition differs for each of the investigated sandstones, i.e. the absolute water content at full saturation can be very different. Furthermore, the suggested fitting curve of Eq. (1) of Hawkins \& McConnell changes if the relative water content goes to infinity. Vásárhelyi \& Ván [3] recalculated the published data and changing Eq. (1) to absolute scale:

$$
\sigma_{c i}(w)=a^{*} e^{-b^{*} w}+c^{*},
$$

where $\sigma_{c}(w)$ is the uniaxial compressive strength (MPa), $w$ is the water saturation $(S)$. The strength at zero water content

$$
\sigma_{c i}(S=0)=a^{*}+b^{*},
$$

and the strength at full saturation

$$
\sigma_{c}(S=1)=a^{*} \exp \left(-100 b^{*}\right)+c^{*},
$$

and statistically $b^{*}$ is 6.0259 [3]. According to Eqs. (1) and (2), the strength of the rock highly (exponentially) depends on the moisture content - there is not significant difference between the half saturated and fully saturated strength (see the results of Kleb and Vásárhelyi [4]). Thus only the dry and fully water saturated conditions are examined in this paper.

Due to water saturation, the mechanical parameters decrease and this ratio is rock type dependent. In Table 1. the ratio of saturated $\left(\sigma_{c i(s a t)}\right)$ and dry $\left(\sigma_{c i(d r y)}\right)$ uniaxial compressive strengths are summarized, using the collection of Zhang [5].

Therefore, we express the uniaxial compressive strength of the intact rock $\left(\sigma_{c i}\right)$ in a single formula for the two petrophysical conditions (i.e. $S=0-$ dry and $S=1$ fully saturated) as indicated in Fig. 2.

$$
\sigma_{c i(s)}=\sigma_{c i 0}(S(\omega-1)+1),
$$

where $\sigma_{c i 0}$ is the strength of the rock at dry condition, and $\omega$ is the ratio according to Table 1 .

An example of the measured saturated strength as a function of dry strength is presented in Fig. 3 (results of [10]).

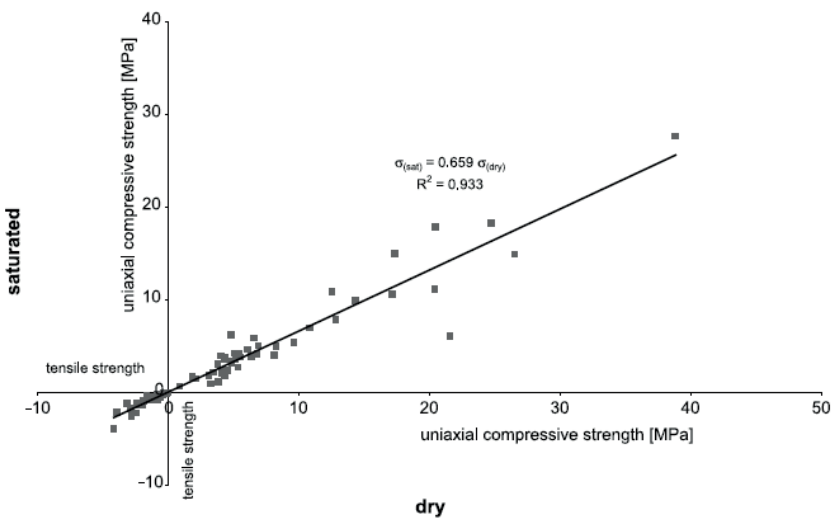

Fig. 3 The measured saturated strength as a function of the dry strength -

\begin{tabular}{|c|c|c|}
\hline $\begin{array}{l}\omega= \\
\sigma_{c(s a t)} / \sigma_{c(d r y)}\end{array}$ & rock & reference \\
\hline 0.50 & Shale and quartzitic sandstone & Colback \& Wild [6] \\
\hline 0.76 & Penrith sandstone & Dyke \& Dobereiner [7] \\
\hline 0.75 & Bunter sandstone & \\
\hline 0.66 & Waterstone & \\
\hline $0.22-0.92$ & 35 British sandstone & Hawkins \& McConnell [2] \\
\hline 0.97 & Oolitic limestone & Lashkaripour \& Ghafoori [8] \\
\hline 0.62 & $\begin{array}{l}\text { Sandstone and sandy } \\
\text { limestone }\end{array}$ & \\
\hline 0.81 & $\begin{array}{l}\text { Oolitic limestone and limy } \\
\text { sandstone }\end{array}$ & \\
\hline 0.52 & Shale & \\
\hline 0.76 & British sandstone & Vásárhelyi [9] \\
\hline 0.66 & Miocene limestone & Vásárhelyi [10] \\
\hline 0.59 & Jastrzebie sandstone & Kwasneski \& Oitaben [11] \\
\hline 0.49 & Anna mudstone & \\
\hline 0.35 & Gypsum & Yilmaz [12] \\
\hline $0.36-0.69$ & Limestone & Rajabzadeh et al. [13] \\
\hline $0.29-0.85$ & Dolomitic limestone & \\
\hline $0.33-0.64$ & Marble & \\
\hline 0.33 & Tuffs from Eger (Hungary) & Kleb \& Vásárhelyi [4] \\
\hline 0.729 & Hungarian tuffs & Vásárhelyi [29] \\
\hline 0.88 & Travertine & Török \& Vásárhelyi [14] \\
\hline
\end{tabular}
miocene limestone [10]

Table 1 Ratio of unconfined compressive strength at saturation condition $\left(\sigma_{c(s a t)}\right)$ to that dry condition $\left(\sigma_{c(d r v y}\right)-\omega$ - for different rock [5]

Similar result was found between the dry and saturated Young's modulus (see Fig. 4). Zhang [5] collected some results (see Table 2). According to the published data, the Young's modulus of the intact rock decreases linearly due to water saturation, i.e.

$$
E_{(s a t)}=E_{(d r y)}(S(\theta-1)+1),
$$

where $S=0$ and $S=1$ in case of dry and fully saturated condition, respectively. (note: for different moisture content the formulas presented in Eqs. (1) and (2) can be used).

Unfortunately, there is not any information about the influence of the water content on the Poisson's ratio - up to now it was not investigated. 


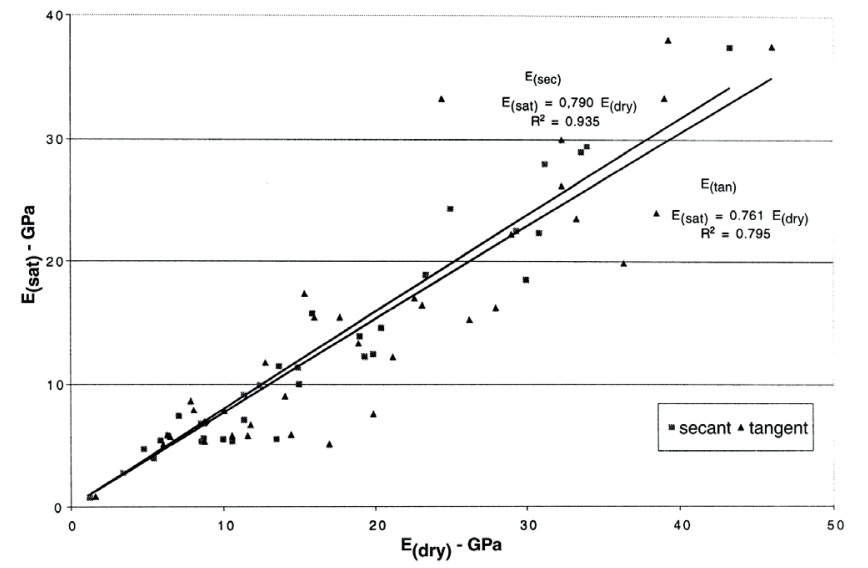

Fig. 4 influence of water content on the tangent and secant Young's modulus - British sandstones [9]

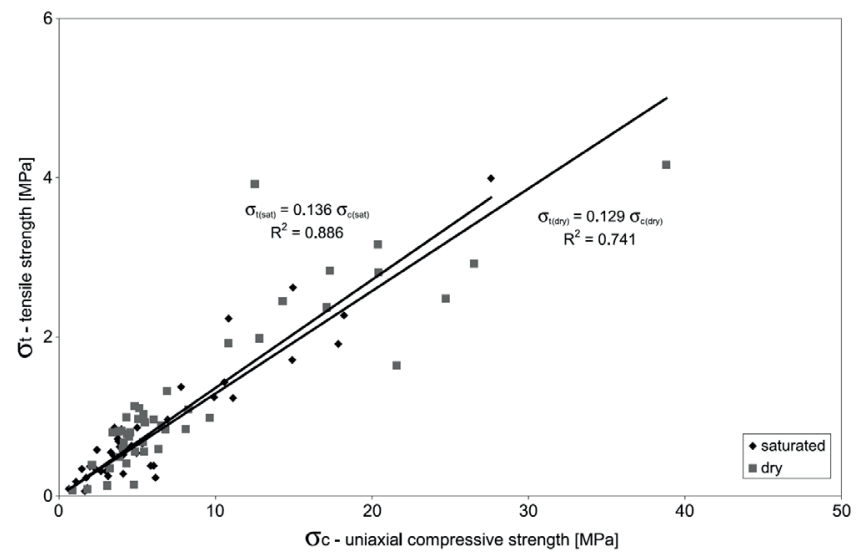

Fig. 5 Tensile strength in function of the uniaxial compressive strength as a dry and saturated condition [10]

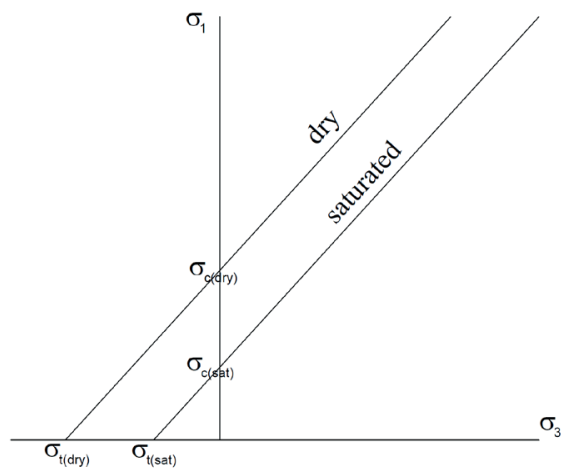

Fig. 6 Influence of the water content on the Coulomb-line

Table 2 Ratio of elastic modulus at saturated condition $E_{(s a t)}$ to dry condition $E_{(d r y)}$ for different rocks [5]

\begin{tabular}{lcc}
\hline$\theta=E_{(s a t)} / E_{(d r y)}$ & rock & reference \\
\hline 0.76 & British sandstone & Vásárhelyi [9] \\
0.66 & Miocene limestone & Vásárhelyi [10] \\
0.68 & Jastrzebie sandstone & Kwasneski \& Oitaben [11] \\
0.34 & Anna mudstone & \\
0.54 & Gypsum & Yilmaz [12] \\
0.81 & Hungarian tuffs & Vásárhelyi [29] \\
0.79 & Andesite & Karakul \& Ulusay [15] \\
0.19 & Ignimbrite & \\
0.32 & Marl & \\
\hline
\end{tabular}

\section{Influence of the water content on the failure of the intact rock}

Vásárhelyi [10] investigated the influence of the water content on the ratio of tensile strength and compressive strength using large number of laboratory tests of high porosity Hungarian Miocene limestones. The ratio of these two mechanical parameters (i.e. uniaxial compressive strength, tensile strength) were constant, thus it is independent on the water saturation (e.g. see Fig. 5).

According to Cai [16], the rigidity of the intact rock can be calculated as the ratio of the uniaxial compressive strength and the Brazilian tensile strength of the rock, i.e.:

$$
R=\frac{\sigma_{c}}{\left|\sigma_{t}\right|} .
$$

Based on the measured and published data, $\mathrm{R}$ is a material constant, which is independent on the water content.

The test dataset compiled by Sheorey [17], although limited in number, shows a large variation of the strength ratio (R), from 2.7 to 39 with an average of 14.7. Vutukuri et al [18] stated that the strength ratio of most rocks varies from 10 to 50 and it is rock type dependent factor.

\subsection{Mohr-Coulomb parameters}

According to the Coulomb failure criteria, the internal friction angle $(\phi)$ can be calculated from the ratio of the uniaxial compressive strength $\left(\sigma_{c}\right)$ and the tensile strength $\left(\sigma_{t}\right)$ :

$$
R=\frac{\sigma_{c}}{\left|\sigma_{t}\right|}=\frac{1+\sin \varphi}{1-\sin \varphi}
$$

as it was shown before, this ratio is independent of the water ratio, thus the internal friction angle is material constant which is not influenced by the moisture content.

The cohesion of the rock (c) parallel decreases of the uniaxial compressive strength (see Eqs. 1 and 2).

The changing of the Coulomb failure criterion due to water saturation is presented in Fig. 6 - the two line should be parallel with each other.

\subsection{Hoek-Brown parameters}

Many laboratory tests were conducted for the development of the Hoek-Brown failure criterion for intact rocks (according to Hoek and Brown [19]):

$$
\sigma_{1}=\sigma_{3}+\sigma_{c}\left(m_{i} \frac{\sigma_{3}}{\sigma_{c}}+1\right)^{0.5},
$$

where $\sigma_{1}$ and $\sigma_{3}$ are the major and minor principal stresses, respectively, $m_{i}$ is a material constant and $\sigma_{c}$ is the UCS of the intact rock.

Cai [16] showed that $m_{i}$ constant in the Hoek-Brown failure criterion (Eq. 6) is equal to the ratio of UCS $\left(\sigma_{c}\right)$ to tensile strength $\left(\sigma_{t}\right)$ (see Eq. 4). This statement is true only if the 
strength ratio is high and it is assumed that the Hoek-Brown failure criterion correctly describes the strength behavior both tension and compression. According the calculation of Cai [16], when $R \geq 8$, the error for approximating $m_{i}$ by $R$ (Eq. 3) is less than $1.6 \%$, thus the Hoek-Brown parameter $\left(m_{i}\right)$ can be calculated using the following form:

$$
m_{i} \approx R=\frac{\sigma_{c}}{\left|\sigma_{t}\right|},
$$

according to Hoek [20], $m_{i}$ values range from 4 to 33 for some commonly encountered rocks in engineering practice and $m_{i}$ depends on many factors such as mineral contents, foliation and grain size (texture) - but as it was shown previously, $m_{i}$ value is independent on the water content.

Shen \& Karakus [21] emphasized the difficulties in determining the $m_{i}$ values of rocks. They suggested to normalize the Hoek-Brown constant $\left(m_{i}\right)$ by using strength of the intact rock $\left(\sigma_{c i}\right)$. The modified version of the Hoek-Brown Eq. (7) is as follows:

$$
\sigma_{1}=\sigma_{3}+\sigma \mathrm{c}\left(m_{i n} \sigma_{3}+1\right) 0.5
$$

Where $m_{i n}=m_{i} / \sigma_{c i}$. Recently, Vásárhelyi et al. [22] analyzed this equation and it was also denoted that the failure envelope of the intact rock can be determined more exactly with the help of this equation. In this case Eq. (3) can be used for determining the $m_{i n}$ value.

\section{Modulus Ratio}

The published data of different British sandstones by Hawkins and McConnell [2] were statistically analysed by Vásárhelyi [9]. He showed that the ratios between different mechanical parameters (such as tangent and secant modulus and uniaxial compressive strength) are independent on the water content. Fig. 7 shows an example of his paper [9]: the ratio of tangent modulus $\left(E_{\tan }\right)$ and uniaxial compressive strength (UCS) are 178 and 174 for dry and saturated states, respectively.

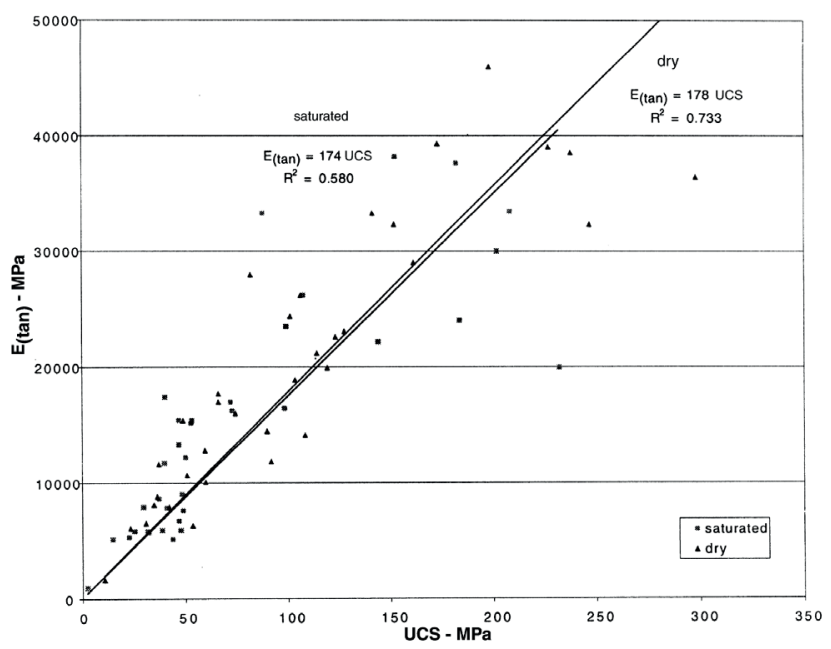

Fig. 7 Relationship between the uniaxial compressive strength (UCS) and the tangent Young's modulus $\left(E_{\text {tan }}\right)$ in dry and saturated conditions [9]
The ratio of the Young modulus $(E)$ and the strength of the rock $\left(\sigma_{c i}\right)$ is the modulus ratio $(M R)$, which can be used for calculations. This parameter is used in rock engineering when deformation of different structural elements of underground storage, caverns, tunnels or mining opening must be computed [23].

According to the measured results, this modulus ratio is independent on the water content, i.e.:

$$
M R=E / \sigma_{c i}=\text { constant }
$$

\section{Rock Mass mechanical parameters}

There are several empirical formulas for calculating the mechanical parameters of the rock mass (see review article by Vásárhelyi \& Kovács [24]). Recently, the generalized HoekBrown failure criterion is widely used in the rock engineering practice.

The generalized Hoek-Brown failure criterion for jointed rock masses is defined by [25]:

$$
\sigma_{1}{ }^{\prime}=\sigma_{3}{ }^{\prime}+\sigma_{c i}\left(m_{b} \frac{\sigma_{3}{ }^{\prime}}{\sigma_{c i}}+1\right)^{a},
$$

where $\sigma_{1}{ }^{\prime}$ and $\sigma_{3}{ }^{\prime}$ are the maximum and minimum effective principal stress at failure; and the Hoek-Brown parameters $m_{b}$, $s$ and $a$ are:

$$
\begin{gathered}
m_{b}=m_{i} e^{\frac{G S I-100}{28-14 D}}, \\
s=e^{\frac{G S I-100}{9-2 D}},
\end{gathered}
$$

and

$$
a=\frac{1}{2}+\frac{1}{6}\left(e^{-G S I / 15}-e^{-20 / 3}\right),
$$

$D$ is a factor which depends upon the degree of disturbance due to blast damage and stress relaxation [25], i.e. this value is independent on the petrophysical state of the rock.

GSI is the Geological Strength Index, can be calculated from the structure of the rock mass and the joint surface quality [20, $26,27]$, thus this value is also independent on the water content.

It means that both Eq. (13) and Eq. (14) are independent on the saturation degree of the rock. As it was presented previously, the Hoek-Brown constant $m_{i}$ is also not changing due to water saturation, i.e. Eq. (11) is independent on the water saturation.

It means, only the strength of the intact rock $\left(\sigma_{c i}\right)$ decreasing in case of increasing moisture content in Eq. (11) - according to Eqs. (1...3).

Applying Eq. (11), the uniaxial compressive strength of the rock mass $\left(\sigma_{r m}\right)$ can be calculated, using the following equation:

$$
\sigma_{r m}=\sigma_{c i} s^{a}
$$

Where $s$ and $a$ constants are independent of the water content and the uniaxial compressive strength of the intact rock $\left(\sigma_{c i}\right)$ can be calculated according to Eq. (3), or using Table 1.

Similarly, the tensile strength of the rock mass $\left(\sigma_{t r m}\right)$ can be calculated as following: 


$$
\sigma_{t r m}=-\frac{s \sigma_{c i}}{m_{b}}
$$

The deformation modulus of the rock mass $\left(E_{r m}\right)$ can be calculated from the Young's modulus of the intact rock $\left(E_{i}\right)$ and the rock mass classification (using e.g. GSI value), using the following form:

$$
E_{r m}=E_{i} e^{\frac{G S I-100}{A}}
$$

where $A$ is an empirical constant (see [24]) - independent value on the petrophysical state. The deformation modulus of the rock mass should be decreasing linearly due to water saturation, according to Eq. (4), it is independent on the rock mass quality.

Ván \& Vásárhelyi [32] suggested the following form for calculating the modulus ratio of the rock mass:

$$
\frac{E_{r m}}{\sigma_{r m}}=\text { MR.e } \mathrm{e}^{\frac{2(\mathrm{GSI}-100)}{100}},
$$

where $M R$ is the modulus ratio of the intact rock (see Eq. 10), $E_{r m}$ and $\sigma_{r m}$ are the deformation modulus (see Eq. 17) and the rock mass strength (see Eq. 15), respectively. According to the results, $\mathrm{MR}$ is a material constant, which is independent on the water content, thus the modulus ratio of the rock mass is also independent on the saturation degree of the rock.

Unfortunately, there is not any published data about the Poisson's ratio value of the rock mass.

Tokshiki and Aydan [33] proposed a direct method of determining the Poisson's ratio from the Rock Mass Rate $(R M R)$ value:

$$
\nu_{\mathrm{rm}}=0.5-0.2 \frac{R M R}{R M R+0.2(100-R M R)} .
$$

Using Eq. (19) the Poisson rate of the rock mass $\left(v_{r m}\right)$ is between 0.3 and 0.5 , independently of the water saturation.

Later, Aydan et al [34] modified Eq. (19). According to their publication, if the Poisson's ratio of the intact rock $\left(v_{i}\right)$ is known, the following relationship can be used to determine the Poisson's ratio of the rock mass $\left(v_{r m}\right)$ in the function of the Rock Mass Rate $(R M R)$ :

$$
\frac{\nu_{\mathrm{rm}}}{\nu_{i}}=2.5-1.5 \frac{R M R}{R M R+(100-R M R)} .
$$

According to Eq. (20), due to water saturation the Poisson ratio of the rock mass $\left(v_{r m}\right)$ has to be changing similarly than the Poisson ratio of the intact rock $\left(v_{i}\right)$.

Vásárhelyi \& Kovács, [24] and Vásárhelyi [28] proposed the following relationship between the Hoek-Brown constant $\left(m_{i}\right)$, the Geological Strength Index $(G S I)$ and the Poisson's ratio of the rock mass $\left(v_{r m}\right)-$ see Fig. 8.:

$$
v_{r m}=-0.002 G S I-0.003 m_{i}+0.457 .
$$

As it was shown previously, both GSI and $m_{i}$ are independent on the water content, thus one may suppose that Poisson's ratio value of the rock mass should be independent, as well,

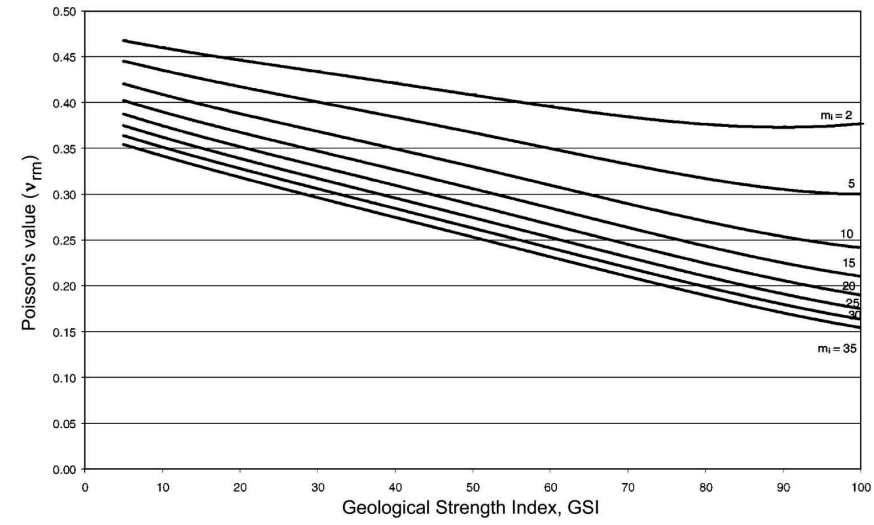

Fig. 8 Estimated Poisson's rate values $\left(v_{r m}\right)$ in the function of the geological strength index $(G S I)$ in case of different Hoek-Brown $\left(m_{i}\right)$ constants [28]

i.e. does not change due to water saturation. (Thus the Poisson ratio of the rock should be independent of the moisture content, as well).

\section{Conclusions}

Generally, due to the water saturation, the mechanical parameters of intact rock decreases. According to the experimental results, the ratio of the dry and saturated mechanical parameters are constants, it is rock material dependent. It should be mentioned, that similar results were obtained for different environmental effects (eg. [35]).

The mechanical parameters of the rock mass similarly depend on the water content than the intact rock, according to the empirical equations [24]. It means, the exact determination of the rock mass quality (e.g. Geological Strength Index - GSI or Rock Mass Rate - RMR) is very important for calculation the mechanical behavior of the rock mass but does not influence by the water content. The sensitivity of GSI based equations were calculated by Ván \& Vásárhelyi [29] and it was found that these relationships are highly dependent on the input parameters changing one parameter with $5 \%$, and the final results may change more than $50 \%$ !

In this paper mostly the results of Hungarian Miocene limestone [10] British sandstones [2, 3, 9] and rhyolitic tuffs from Eger (Hungary) [4] were analyzed, but similar results were found for other Hungarian tuffs [30] and these results can be used in general [31]. Notably, for a more precise and fundamental description of the mechanical behavior of rock, one should apply non-equilibrium continuum thermodynamics along the lines of $[36,37]$ and beyond. The similarity of the regression lines for the different rock types was unexpected from a theoretical point of view, although it is of note that a similar relationship has been reported as a consequence of damage related thermodynamic stability [38, 39].

\section{Acknowledgement}

The project presented in this article is supported by National Research, Development and Innovation Office - NKFIH 124366 and NKFIH 124508. 


\section{Nomenclature}

c cohesion

E Young's modulus

GSI Geological Strength Index

$m_{i} \quad$ Hoek-Brown parameter of intact rock

$M R$ modulus ratio

$R M R$ Rock Mass Rate

$S$ water saturation

$w \quad$ water content

$\phi \quad$ internal friction angle

$v \quad$ Poisson ratio

$\sigma_{c i} \quad$ uniaxial compressive strength

$\sigma_{t} \quad$ tensile strength

\section{References}

[1] Wong, L. N. Y., Maruvanchery, V., Liu, G. "Water effects on rock strength and stiffness degradation". Acta Geotechnica, 11(4), pp. 713-737, 2016. https://doi.org/10.1007/s11440-015-0407-7

[2] Hawkins, A. B., McConnell, B. J. "Sensitivity of sandstone strength and deformability to changes in moisture content". Quarterly Journal of Engineering Geology and Hydrogeology, 25(2), pp. 115-130, 1992. https://doi.org/10.1144/GSL.QJEG.1992.025.02.05

[3] Vásárhelyi, B., Ván, P. "Influence of water content on the strength of rock". Engneering Geology, 84(1-2), pp. 70-74, 2006. https://doi.org/10.1016/j.enggeo.2005.11.011

[4] Kleb, B., Vásárhelyi, B. "Test results and empirical formulas of rock mechanical parameters of rhiolitic tuff samples from Eger's cellars". Acta Geologica Hungarica, 46(3), pp. 301-312, 2003.

https://doi.org/10.1556/AGeol.46.2003.3.5

[5] Zhang, L. "Engineering properties of rocks". 2nd ed., Elsevier, NewYork, United States, 2017.

[6] Colback, P. S. B., Wild, B. L.: "The influence of moisture content on the compressive strength". In: Proceedings of the 3rd Canadian Rock Mechanics Symposium, Toronto, Canada. 1965. pp. 65-83.

[7] Dyke, C. G., Dobereiner, L.: "Evaluating the strength and deformability of sandstones". Quarterly Journal of Engineering Geology and Hydrogeology, 24(1), pp.123-134, 1991.

https://doi.org/10.1144/GSL.QJEG.1991.024.01.13

[8] Lashkaripour, G. R., Ghafoori, M. "The engineering geology of the Tabarak Abad Dam". Engineering Geology, 66(3-4), pp. 233-239, 2002. https://doi.org/10.1016/S0013-7952(02)00044-3

[9] Vásárhelyi, B. "Some observation regarding the strength and deformability of sandstones in case of dry and saturated conditions". Bulletin of Engineering Geology and the Environment, 62(3), pp. 245-249, 2003. https://doi.org/10.1007/s10064-002-0186-x

[10] Vásárhelyi, B. "Statistical analysis of the influence of water content on the strength of the Miocene limestone". Rock Mechanics and Rock Engineering, 38(1), pp. 69-76, 2005. https://doi.org/10.1007/s00603-004-0034-3

[11] Kwasniewski, M., Oitaben, P. R. "Effect of water on defrmability of rocks under uniaxial compression". In: ISRM Regional Symposium - EUROCK 2009, Cavtat, Croatia, 2009. pp. 271-276.

[12] Yilmaz, I. "Influence of water content on the strength and deformability of gypsum". International Journal of Rock Mechanics and Mining Sciences, 47(2), pp. 342-347, 2010.

https://doi.org/10.1016/j.ijrmms.2009.09.002
[13] Rajabzadeh, M. A., Moosavinasab, Z., Rakhshandehroo, G. "Effects of rock classes and porosity on the relation between uniaxial compressive strength and some rock properties for carbonate rocks". Rock Mechanics and Rock Engineering, 45(1), pp. 113-122, 2012. https://doi.org/10.1007/s00603-011-0169-y

[14] Török, Á., Vásárhelyi, B. "The influence of fabric and water content on selected rock mechanical parameters of travertine, examples from Hungary". Engineering Geology, 115(3-4), pp. 237-245, 2010. https://doi.org/10.1016/j.enggeo.2010.01.005

[15] Karakul, H., Ulusay, R. "Empirical correlations for predicting strength properties of rocks from P-wave velocity under different degrees of saturation". Rock Mechanics and Rock Engineering, 46(5) pp. 981-999. 2013. https://doi.org/10.1007/s00603-012-0353-8

[16] Cai, M. "Practical Estimates of Tensile Strength and Hoek-Brown Strength Parameter mi of Brittle Rocks". Rock Mechanics and Rock Engineering, 43(2), pp. 167-184, 2010. https://doi.org/10.1007/s00603-009-0053-1

[17] Sheorey, P. R. "Empirical rock failure criteria", 1nd ed., A. A. Balkema, Rotterdam, Netherlands, 1997.

[18] Vutukuri, V. S., Lama, R. D., Saluja, S. S. "Handbook on mechanical properties of rocks, vol I. - testing techniques and results". 1nd ed., Trans Tech Publications, Bay Village, Ohio, 1974.

[19] Hoek, E., Brown, E. T. "Empirical strength criterion for rock masses". Journal of the Geotechnival Engineering Division, 106(9), pp. 10131035, 1980.

[20] Hoek, E. "Practical rock engineering". Evert Hoek Consulting Engineer Inc., North Vancouver, Canada, 2007. http://www.rocscience.com

[21] Shen, J., Karakus, M. "Simplified method for estimating the Hoek-Brown constant for intact rocks". Journal of Geotechnical and Geoenvironmental Engineering, 140(6), 2014. https://doi.org/10.1061/(ASCE)GT.1943-5606.0001116

[22] Vásárhelyi, B., Kovács, L., Török, Á. "Analysing the modified HoekBrown failure criteria using Hungarian granitic rock". Geomechanics and Geophysics for Geo-Energy and Geo-Resources, 2(2), pp. 131-136, 2016. https://doi.org/10.1007/s40948-016-0021-7

[23] Palmström, A., Singh, R. "The deformation modulus of rock masses comparisons between in situ tests and indirect estimates". Tunnelling and Underground Space Technology, 16(2), pp. 115-131, 2001. https://doi.org/10.1016/S0886-7798(01)00038-4

[24] Vásárhelyi, B., Kovács, D. "Empirical methods of calculating the mechanical parameters of the rock mass". Periodica Polytechnica Civil Engineering, 61(1), pp. 39-50, 2017. https://doi.org/10.3311/PPci.10095

[25] Hoek, E., Carranza-Torres, C. T., Corkum, B. "Hoek-Brown failure criterion-2002 edition". In: Proceedings of the 5th North American Rock Mechanics Symposium, Toronto, Canada, 2002. pp. 267-273.

[26] Vásárhelyi, B., Somodi, G., Krupa, Á., Kovács, L. "Determining the Geological Strength Index (GSI) using difference method". In: Rock Mechanics and Rock Engineering: From the Past to the Future, Cappadocia, Turkey, 2016. pp. 1049-1054.

[27] Somodi, G., Krupa, Á., Kovács, L., Vásárhelyi, B. "Comparison of different calculation methods of Geological Strength Index (GSI) in a specific underground construction site". Engineer Geology, 243(4), pp. 50-58, 2018. https://doi.org/10.1016/j.enggeo.2018.06.010

[28] Vásárhelyi, B. "A possible method for estimating the Poisson's rate values of the rock masses". Acta Geodaetica et Geophysica Hungarica, 44(3), pp. 312-322, 2009.

https://doi.org/10.1556/AGeod.44.2009.3.4 
[29] Ván, P., Vásárhelyi, B. "Sensitivity analysis of GSI based mechanical parameters of the rock mass". Periodica Polytechnica Civil Engineering, 58(4), pp. 379-386, 2014.

https://doi.org/10.3311/PPci.7507

[30] Vásárhelyi, B. "Influence of the water saturation for the strength of volcanic tuffs". In: Workshop on volcanic rocks. Lisbon, Portugal, 2002. pp. 89-96.

[31] Romana, M., Vásárhelyi, B. "A discussion on the decrease of unconfined compressive strength between saturated and dry rock samples". In: The Second Half Century of Rock Mechanics, Three Volume Set: 11th Congress of the International Society for Rock Mechanics. Lisbon, Portugal, 2007. pp. 139-142.

[32] Ván, P., Vásárhelyi, B. "Relation of rock mass characterization and damage". In: Eurock 2009 - Rock Engineering in Difficult Ground Conditions - Soft Rock and Karst, 1st ed., Taylor\&Francis Group, London, United Kingdom, 2010. pp. 399-404.

[33] Tokashiki, N., Aydan, Ö. "The stability assessment of overhanging Ryukyu limestone cliffs with an emphasis on the evaluation of tensile strength of rock mass". Doboku Gakkai Ronbunshuu C, 66(2), pp. 397-406. 2010. https://doi.org/10.2208/jscejc.66.397

[34] Aydan, Ö, Tokashiki, N., Genis, M. "Some considerations on yield (failure) criteria in rock mechanics". In: Proceedings of the 46th US rock mechanics/geomechanics symposium, Chicago, Illinois, 2012. https://www. onepetro.org/conference-paper/ARMA-2012-640
[35] Pápay, Z., Török, Á. "Effect of Thermal and Freeze-thaw Stress on the Mechanical Properties of Porous Limestone". Periodica Polytechnica Civil Engineering, 62(2), pp. 423-428, 2018. https://doi.org/10.3311/PPci.11100

[36] Asszonyi, Cs., Csatár, A., Fülöp, T. "Elastic, thermal expansion, plastic and rheological processes - theory and experiment". Periodica Polytechnica Civil Engineering, 60(4), pp. 591-601, 2016.

https://doi.org/10.3311/PPci.8628

[37] Asszonyi, Cs., Fülöp, T., Ván, P. "Distinguished rheological models for solids in the framework of a thermodynamical internal variable theory". Continuum Mechanics and Thermodynamics, 27(6), pp. 971-986, 2015. https://doi.org/10.1007/s00161-014-0392-3

[38] Ván, P. "Thermodynamic variables and the failure of microcracked materials". Journal of Non-Equilibrium Thermodynamics, 26(2), pp. 167-189, 2001. https://doi.org/10.1515/JNETDY.2001.012

[39] Ván, P., Vásárhelyi, B. "Second law of thermodynamics and the failure of rock materials". In: DC Rocks 2001, The 38th U.S. Symposium on Rock Mechanics (USRMS), Washington, D.C., United States, 2001. pp. 767-776. 